\begin{tabular}{ccc}
\hline International Journal of Engineering \& Technology, $7(4.34)(2018) 480-483$ \\
SPC \\
Website w ww. sciencepubco.com/index.php/IJET \\
Research paper
\end{tabular}

\title{
The Influence of Travel Motivation on Satisfaction and Intention to Visit Terengganu
}

\author{
Tewfik Mohammed Hazaea Hasan ${ }^{1}$, Ahmad Puad Mat Som*, Fathilah Ismail² \\ ${ }^{1}$ Faculty of Applied Social Sciences, Universiti Sultan Zainal Abidin, Gong Badak Campus, 21300 Kuala Nerus, Terengganu, Malaysia \\ ${ }^{2}$ School of Maritime Business and Management, Universiti Malaysia Terengganu, 21300 Kuala Nerus, Terengganu, Malaysia \\ *Corresponding author E-mail: puadms@unisza.edu.my
}

\begin{abstract}
Tourism is considered one of the fundamental industries worldwide, which has the potential to strengthen economic development. In 2017 only, tourist comings to Malaysia generated a national income of RM49.6 billion. This study aims to determine whether tourists are gratified with their visit to Terengganu for tourism and to explore the factors influencing the tourist satisfaction by push and pull travel motivations. The tourists' perceptions are important since they could be used to determine the degree of their contribution to the development of tourism. The findings indicated that the overall tourist satisfaction with their visit to Terengganu is high, with a mean value of 3.84. The findings also showed that factors influencing the tourists to visit Terengganu are hospitality of the service providers, friendly attitude of the local communities, local culture, and attractive scenery. There is a need for concerted efforts to increase the tourists' satisfaction since it influences their intention for future visit to the state.
\end{abstract}

Keywords: Travel Motivation; Satisfaction; Intention; Terengganu.

\section{Introduction}

It is reported that about 3.5 trillion US dollars has been generated in the tourism industry, and this income is expected to increase to 7 trillion dollars in 2019 [1]. About one billion tourists around the world are expected to cross borders in the next five years. As a result, it is predicted that the tourism industry will become an important factor for socioeconomic development, which will contribute to the growth of Malaysian economy as a developing nation. In terms of contribution to Malaysia's economic growth, tourism is considered the second largest industry apart from the manufacturing sector. An authorized record indicated that the total number of international tourists who visited Malaysia in 2017 amounted to 25.9 million. As a result, a national income of about RM82.2 billion was generated [2].

Tourism Malaysia serves as the Malaysia's primary agency of tourism. This agency has tremendously contributed to the promotion of Malaysia as a tourist destination using various marketing and promotional approaches. All types of advertising adopt the theme 'Malaysia Truly Asia' as a slogan. In early 2008, 'Cuti-Cuti Malaysia' and 'Zoom Malaysia' were immensely promoted all over the country to promote domestic tourism. Tourism Malaysia remains the major promoter of tourism destinations, as well as the various kinds of other tourism niches which the country can provide, for instances, island tourism, ecotourism, cultural tourism, and heritage tourism [3].

Terengganu is amongst the states situated on the East-Coast of Peninsular Malaysia. The state is blessed with numerous traditional cultural inheritances which were established thousands of years ago. The traditional lifestyle of Malay people and their distinctive culture are consistent with the structures of the present tourism product desired by both local and international tourists. A number of development strategies have been engaged by the Terengganu state government to safeguard the protraction and continuity of these tourism products and their future demand.

\section{Literature Review}

\subsection{Motivation}

Motivation is mostly described as biological or psychological desires and needs, as well as essential forces that produce, direct, and incorporate an individual's conduct and action [4-6]. It can be seen as a complex proposal to examine people's reasons for travel and the satisfaction they derive out of it, since a tourism paradigm is at all times associated with mankind and human nature. Various approaches were used to explain the characteristics and issues associated with motivation. The meaning of motivation focuses on cognitive and emotional motives [7] or internal and external motives [8] in the fields of sociology and psychology. An internal motive is related with instincts, moods, and motivations while external motive encompasses mental pictures including beliefs or knowledge. From an anthropological perspective, most tourists' motivations are aimed at avoidance of the daily life routine, in search of realistic experiences [9]. From socio-psychological perspective, motivation can be categorized into two dimensions: avoidance and seeking [10].

In tourism research, the concept of motivation can be classified into two motives, which shows that individuals travel for the reason that they are pulled or pushed to do so by some factors or forces $[11,4]$. These forces define how people are pushed for by the variables of motivation into making decisions for travel and how they are attracted or pulled by the characteristics of a particular destination [6]. This means that the push motivations are associated with the tourist's aspiration while pull motivations are re- 
lated with the characteristics of the particular destination $[12,13$, $4,6]$.

Evidently, emotional or internal features are connected with push motivation, while situational, external, or cognitive features are associated with pull motivation. Basically, push motivation is described as the need for avoidance, recreation and leisure, reputation, well-being and health, exploration and social relations, personal intimacy, and enjoyment [13]. Tourists may perhaps travel in order to avoid daily routine and look for genuine experiences. A pull motivation is usually motivated by the desirability of a particular destination, such as recreation services, beaches, cultural fascinations, natural scenery, entertainment, parks, and shopping. These destination characteristics could motivate and strengthen intrinsic push motivations [14]. Numerous studies were carried out from these viewpoints $[10,15,16]$.

\subsection{Satisfaction}

Satisfaction plays an essential role in the development of highly demanded tourism services and products. Essentially, tourist satisfaction is a significant aspect of fruitful destination promotion for the reason that it effects the consumption of services and products, the decision to come again, and the destination choice [17]. Some scholars focused on the evaluation of standards employed in the quality of service and gratification and offered various methods of satisfaction and service quality $[18,19]$. Knowledge of satisfaction is considered to be an important factor employed to assess the standard of products and services of particular destination [20, 21]. In tourism literature, several viewpoints and concepts are used to evaluate tourist satisfaction.

The disconfirmation/expectation models have been extensively used in many studies to evaluate consumer satisfaction [22-24], equity [25, 26], norm [27], and observed general performance [28] These models are generally used for evaluation of consumer satisfaction. The disconfirmation/expectation model developed by [24] presumes that consumers or clients are motivated toward developing expectations about a particular product or service before purchase or subscription, and they subsequently compare the authentic standards with their own anticipations. If the actual standard is higher than the consumer's anticipations, this results in positive disconfirmation, meaning that the client is very much gratified and might be more enthusiastic to buy the product over again. If the actual standard is less than the consumer's expectations, this results in negative disconfirmation, meaning that the client is not satisfied and might probably search for different products for the subsequent consumptions. [22] discovered that tourist satisfaction is dependent upon the relationship between the consumer's expectation about the place and the perceived evaluative result of the destination experience. This is basically the outcome of a comparison between the consumer's prior destination images and what he/she truly realizes, accomplishes, and feels at that particular destination. In equity theory, customer satisfaction is considered as a connection between the expenses which the customer incurred and the benefits or rewards which he/she expects [26]. At this point, effort, value, time, and benefits are very important elements influencing satisfaction [29]. Therefore, it is possible to say that if tourists achieve any value or benefits as a result of their effort, money, and time for travel to a destination, such place is valuable.

\subsection{Intention}

[30] described subjective norm intention as the opinion of other individuals who are very important to a person and have an influence in the person's decision-making [31, 32]. Accordingly, the scholar suggested that the purposes of tourists for visiting the country might be subjective to the views of other individuals who are very important to the tourists. [30] also clarified that subjective norm consists of a person's normative views about the reason why such important individuals think of his/her decision to perform the visit, and the amount of the person's enthusiasm to obey these referents $[33,34]$. If a spouse or a parent has not agreed with the person's decision to travel to Malaysia as a tourist, the person's desire to explore Malaysia might be relatively low. Many studies $[35,36]$ showed that the association between intention and satisfaction could be more powerful in collectivistic nations like Malaysia than in individualistic nations like Europe. The findings of some studies by [37] and [36] showed that satisfaction can have a positive impact on intention to select a destination for holidays. This suggests that subjective norm can influence the foreign tourists' intention to visit Malaysia.

\section{Methodology}

This study was designed as a quantitative study. For the purpose of this study, survey was conducted to find out the mediating effect of satisfaction on the relationship between push, pull factors and intention to visit using questionnaire. Related secondary data was reviewed from the literature and previous research to verify the hypotheses. Simple random sampling technique was used to collect sample, since it was the most effective method and a virtuous choice when the target population for this study has been known. According to $[38,39]$ selection table, a sample size of this study was 384 , derived from the sample of the population of tourists visiting Terengganu.

The study evaluated the distribution of the data across some demographic characteristics of the respondents. Based on this study, the respondents were asked to indicate their gender, age, ethnic, educational level, marital status, number of visit/trips to Terengganu, most recent travel to Terengganu, purpose of travel to Terengganu, types of accommodation in Terengganu in the trip, duration of stay in Terengganu in the trip, travel partner, information about Terengganu prior to the trip. The quantitative analysis of the responses obtained from the questionnaire was summarized and portrayed clearly. Statistical analysis using the Statistical Package for Social Sciences (SPSS), version 22.0, was utilized to analyse the data.

\section{Results and Discussion}

The study started with the discussion of data entry and examination of missing data in order to have a clean data. Below are tables showing how respondents are distributed according to the selected demographic characteristics.

Table 1: Gender of Respondents

\begin{tabular}{c|ccccc}
\multicolumn{5}{c}{ Table 1: Gender of Respondents } \\
\hline \multirow{3}{*}{ Valid } & Gender & Frequency & Percent & Cumulative Percent \\
\hline & Male & 250 & 65.1 & 65.1 \\
& Female & 134 & 34.9 & 100 \\
& Total & 384 & 100.0 & \\
\hline
\end{tabular}

Table 1 showed that majority of the respondents in the study were males. Out of 384 respondents, $65.1 \%$ were male respondents, while the remaining $34.9 \%$ were female respondents.

Table 2: Number of Visit to Terengganu in the Past

\begin{tabular}{c|c|c|c|c}
\hline \multirow{4}{*}{ Valid } & $\begin{array}{c}\text { Frequency } \\
\text { of Visit }\end{array}$ & Frequency & Percent & $\begin{array}{c}\text { Cumulative } \\
\text { Percent }\end{array}$ \\
\hline \multirow{4}{*}{} & First time & 220 & 57.3 & 56.6 \\
& Second time & 110 & 28.6 & 82.5 \\
& Third time & 16 & 4.2 & 91.0 \\
& Fourth time & 24 & 6.3 & 96.7 \\
& Fifth time & 4 & 1.0 & 97.6 \\
& More than five time & 8 & 2.1 & 99.5 \\
& Unsure & 2 & 0.5 & 100 \\
& Total & 384 & 100.0 & \\
\hline
\end{tabular}

Table 2 revealed that $57.3 \%$ of respondents were first timers to the state. $28.6 \%$ of them indicated that they were in their second visit 
to Terengganu. A smaller percentage indicated more frequent visitation to the state in the past.

Table 3: Purpose of Visit to Terengganu

\begin{tabular}{c|ccccc}
\hline \multirow{4}{*}{ Valid } & $\begin{array}{c}\text { Purpose } \\
\text { of Visit }\end{array}$ & Frequency & Percent & $\begin{array}{c}\text { Cumulative } \\
\text { Percent }\end{array}$ \\
\hline \multirow{4}{*}{} & Leisure & 330 & 85.9 & 85.9 \\
& Business & 10 & 2.6 & 80.2 \\
& Visit friends & 4 & 1.0 & 81.1 \\
& and relatives & & & \\
& Other & 20 & 5.2 & 100 \\
& Total & 384 & 100.0 & \\
\hline
\end{tabular}

Table 3 above showed that $85.9 \%$ visited Terengganu for leisure purpose, followed by business, visiting friends and relatives and other purposes.

Table 4: Summary of Hypotheses

\begin{tabular}{|c|c|c|c|c|c|c|c|}
\hline & $\begin{array}{c}\text { Path } \\
\text { Coeffic } \\
\text { ients }\end{array}$ & $\begin{array}{c}\text { Sample } \\
\text { Mean } \\
(\mathrm{M})\end{array}$ & $\begin{array}{l}\text { Standard } \\
\text { Deviation } \\
\text { (STDEV) }\end{array}$ & $\begin{array}{c}\mathrm{T} \\
\text { Statistics } \\
\text { (|O/STDE } \\
\text { VD) }\end{array}$ & $\begin{array}{c}\text { P } \\
\text { Values }\end{array}$ & $\mathrm{R}^{2}$ & $\begin{array}{l}\text { Deci } \\
\text { sion }\end{array}$ \\
\hline Intention & & & & & & 0. & \\
\hline $\begin{array}{l}\text { Pull } \rightarrow \\
\text { Intention } \\
\text { Push } \rightarrow\end{array}$ & 0.26 & 0.25 & 0.1 & 2.67 & 0.01 & & $\begin{array}{l}\text { Acce } \\
\text { pt } \\
\text { Acce }\end{array}$ \\
\hline $\begin{array}{l}\text { Intention } \\
\text { Pull } \rightarrow\end{array}$ & 0.16 & 0.16 & 0.07 & 2.32 & 0.02 & & $\begin{array}{l}\text { pt } \\
\text { Acce }\end{array}$ \\
\hline $\begin{array}{l}\text { Satisfaction } \\
\text { Push - }\end{array}$ & 0.71 & 0.71 & 0.04 & 19.09 & 0.00 & & $\begin{array}{l}\text { pt } \\
\text { Acce }\end{array}$ \\
\hline $\begin{array}{l}\text { Satigfaction } \\
\text { Satisfaction }\end{array}$ & 0.23 & 0.23 & 0.04 & 5.57 & 0.00 & & $\begin{array}{l}\text { pt } \\
\text { Acce }\end{array}$ \\
\hline Intention & 0.38 & 0.38 & 0.09 & 4.32 & 0.00 & & $\mathrm{pt}$ \\
\hline
\end{tabular}

Table 4 shows that the standardized beta estimates, Sample Mean (M), Standard Deviation (STDEV), T Statistics (|O/STDEV|) and the probability value (P-value) with the result of the respective construct of this study. $\mathrm{H}_{1}$ posited that there is significant relationship between pull and intention to visit Terengganu. The result of the direct effect showed that the hypothesised relationship between pull and intention to visit Terengganu is positive and statistically significant. The beta estimate in the relationship between pull and intention to visit Terengganu is 0.26 with probability value of $(0.010)$, which is less than the level of 0.05 . This research hypothesis is supported by the data. The study concluded that pull factor has significant positive effect on intention to visit the state. Furthermore, the insignificant effect of pull on intention of international tourists visiting Terengganu implied that the pull factors such as easy accessibility and scenic seaside play a very little role in influencing the international tourists to return or to spread positive word-of-mouth about Terengganu. The tourism organisations in Terengganu should pay more attention in providing good services to tourists, so as to increase repeat visitation and spread positive word-of-mouth promotion.

$\mathrm{H} 2$ posited that there is a significant relationship between push and intention to visit Terengganu. The result of the direct effect showed that the hypothesised relationship between push and intention to visit Terengganu is positive and statistically significant. The beta estimate in the relationship between pull and intention to visit is 0.16 with probability value of $(0.020)$, which is less than the level of 0.05 .

The significant effect of push on intention to visit Terengganu means that the higher the level of push such as knowledge seeking and relaxation, the more the intention to revisit in future, encouraging other people to visit and recommending the destination to family and friends. When the pushing factors are satisfied, they would directly influence the intention to visit.

Additionally, H3 posited that there is significant relationship between pull and satisfaction to visitation. The result of the direct effect showed that the hypothesised relationship between pull, satisfaction and visitation is positive and statistically significant The beta estimate in the relationship between pull and satisfaction in visitation is 0.23 with probability value of $(0.000)$ which is less than the level of 0.05 . This research hypothesis is supported by the data. The study concluded that pull has significant positive effect on satisfaction in their visit to Terengganu.

This study concludes that push factors had significant effect on satisfaction. The significant effect of push on satisfaction means that the higher the push factors such as seeking for knowledge about Terengganu by the tourists, the higher the tourists' satisfaction as reflected by the result of the study. $\mathrm{H} 4$ posited that there is a significant relationship between push and satisfaction in tourists' visitation to Terengganu. The result of the direct effect showed that the hypothesised relationship between push and satisfaction is positive and statistically significant. The beta estimate in the relationship between push and satisfaction is 0.38 with probability value of $(0.000)$ which is less than the level of 0.05 . This research hypothesis is supported by the data. The study concluded that push has significant positive effect on satisfaction on their visitation to Terengganu. Hypothetically, motivation influences tourist satisfaction with travel experiences about the nature of the intention or its attributes. This means that foreign tourists visiting Terengganu were pulled by a set of intention attributes such as quality of beaches, easy accessibility to social amenities and seaside.

\section{Conclusion}

Based on the findings of this study, the development of industrial direction in tourism industry is significantly important in strategizing business sustainability pertaining to business growth. Thus, it needs to conduct comprehensive research to understand the differing characters of travelers who are satisfied with their visitation to Terengganu for future research. This study recommends extending the social exchange theory by including a new variable - residents and tourists' perception of tourism impact.

\section{Acknowledgement}

The authors acknowledge the FRGS (Fundamental Research Grant Scheme, RR154) for completion of this article. The authors would like to thank the Research Management, Innovation and Commercialization Centre, Universiti Sultan Zainal Abidin, Terengganu, Malaysia for providing the financial assistance to support the publication fee of this article.

\section{References}

[1] Coccossis, H., \& Alexandra, M. (2017). The challenge of tourism carrying capacity assessment: Theory and practice. Routledge.

[2] Salleh, M., Omar, K., Yaakop, A. Y., \& Mahmmod, A. R. (2013) Tourist satisfaction in Malaysia. International Journal of Business and Social Science, 4(5), 221-226.

[3] Ormond, M., \& Sulianti, D. (2017). More than medical tourism: lessons from Indonesia and Malaysia on South-South intra-regiona medical travel. Current Issues in Tourism, 20(1), 94-110.

[4] Dann, G. M. (1981). Tourist motivation an appraisal. Annals of Tourism Research, 8(2), 187-219.

[5] Pearce, L. P. (1982). Perceived changes in holiday destinations. Annals of Tourism Research, 9(2), 145-164

[6] Uysal, M., \& Hagan, L. A. R. (1993). Motivation of pleasure travel and tourism. In Khan, M., Olsen, M. \& Var, T. (Eds.) Encyclopedia of Hospitality and Tourism, pp. 798-810.

[7] Ajzen, I., \& Fishbein, M. (1977). Attitude-behavior relations: A theoretical analysis and review of empirical research. Psychological Bulletin, 84(5), 888-894.

[8] Gnoth, J. (1997). Tourism motivation and expectation formation. Annals of Tourism Research, 24(2), 283-304.

[9] MacCannell, D. (1977). The tourist. Schockon.Mannell.

[10] Iso-Ahola, S. E. (1982). Toward a social psychological theory of tourism motivation: A rejoinder. Annals of Tourism Research, 9(2), 256-262.

[11] Dann, G. (1977). Anomie ego-enhancement and Tourism. Annals of Tourism Research, 17, 155-69. 
[12] Cha, S., McCleary, K., \& Uysal, M. (1995). Travel motivations of Japanese overseas travellers: A factor-cluster segmentation approach. Journal of Travel Research, 34(1), 33-39.

[13] Crompton, J. L. (1979). Motivations for pleasure vacation. Annals of Tourism Research, 6(4), 408-424.

[14] McGehee, N. G., Loker-Murphy, L., \& Uysal, M. (1996). The Australian international pleasure travel market: Motivations form a gendered perspective. Journal of Tourism Studies, 7(1), 45-57.

[15] Pyo S, Mihalik BJ, Uysal M (1989) Attraction attributes and motivations: A canonical correlation analysis. Annals of Tourism Research, 16, 277-282.

[16] Yuan, S. \& McDonald, C. (1990). Motivational determinants of international pleasure time. Journal of Travel Research, 24(1), 4244.

[17] Kozak, M., \& Rimmington, M. (2000). Tourist satisfaction with Mallorca, Spain, as an off-season holiday destination. Journal of Travel Research, 38(3), 260-269.

[18] Ekinci, Y., Riley, M., \& Chen, J. S. (2001). A review of comparison standards used in service quality and customer satisfaction studies: Some emerging issues for hospitality and tourism research. Consumer Psychology of Tourism, Hospitality and Leisure, 2, 321-332.

[19] Liljander, V. (1994). Modeling perceived service quality using different comparison standards. Journal of Consumer Satisfaction, Dissatisfaction and Complaining Behavior, 7, 126-142.

[20] Noe, F. P., \& Uysal, M. (1997). Evaluation of outdoor recreational settings: A problem of measuring user satisfaction. Journal of Retailing and Consumer Services, 4(4), 223-230.

[21] Schofield, P. (2000). Evaluating castlefield urban heritage park from the consumer perspective: Destination attribute importance, visitor perception, and satisfaction. Tourism Analysis, 5(2-4), 183 189.

[22] Chon, K. (1989). Understanding recreational travelers' motivation, attitude and satisfaction. The Tourist Review, 44(1), 3-7.

[23] Francken, D. A., \& Raaij, W. (1981). Satisfaction with leisure time activities. Journal of Leisure Research, 13(4), 337-352.

[24] Godbey, G., Crawford, D. W., \& Shen, X. S. (2010). Assessing hierarchical leisure constraints theory after two decades. Journal of Leisure Research, 42(1), 111-134.

[25] Oliver, R. L. (1980). A cognitive model of the antecedents and consequences of satisfaction decisions. Journal of Marketing Research, 17, 46-49.

[26] Fisk, R. P., \& Young, C. E. (1985). Disconfirmation of equity expectations: Effects on consumer satisfaction with services. In E. Hirschman, \& H. Holbrook (Eds.), Advances in Consumer Research. Utah: Association for Consumer Research, pp. 340-345.

[27] Oliver, R. L., \& Swan, J. E. (1989). Consumer perceptions of interpersonal equity and satisfaction in transactions: A field survey approach. Journal of Marketing, 53, 21-35.

[28] Cadotte, E. R., Woodruff, R. B., \& Jenkins, R., L. (1987) Expectations and norms in models of consumer satisfaction. Journal of Marketing Research, 24(3), 305-314.

[29] Tse, D., \& Wilton, P. (1988). Models of consumer satisfaction formation: An extension. Journal of Marketing Research, 25(2), 204-212.

[30] Heskett, J. L., Sasser, W. E., \& Schlesinger, L. A. (1997). The service profit chain. Free Press.

[31] Ajzen, I. (1991). The theory of planned behavior. Organizational Behavior and Human Processes, 50, 179-211.

[32] Han, J. L., Demorest, P. B., Van Straten, W., \& Lyne, A. G. (2009) Polarization observations of 100 pulsars at $774 \mathrm{MHz}$ by the Green Bank Telescope. The Astrophysical Journal Supplement Series, 181(2), 557-571.

[33] Trafimow, D., \& Finlay, K. A. (1996). The importance of subjective norms for a minority of people: Between-subjects and within-subjects analyses. Personality and Social Psychology Bulletin, 22,820-828.

[34] Eagly, A. H., \& Chaiken, S. (1993). The psychology of attitudes. Harbourt Brace College Publishers.

[35] Ajzen, I., \& Fishbein, M. (1980). Understanding attitudes and predicting social behavior. Prentice-Hall.

[36] Bagozzi, R., Gurhan-Canli, Z., \& Priester, J. (2002). The social psychology of consumer behaviour. McGraw-Hill Education.

[37] Quintal, V. A., Lee, J. A., \& Soutar, G. N. (2010). Risk, uncertainty and the theory of planned behavior: A tourism example. Tourism Management, 31(6), 797-805.

[38] Cheng, S., Lam, T., \& Hsu, C. H. (2006). Negative word-of-mouth communication intention: An application of the theory of planned behavior. Journal of Hospitality and Tourism Research, 30(1), 95116.

[39] Krejcie, R. V., \& Morgan, D. W. (1970). Determining sample size for research activities. Educational and Psychological Measurement, 30(3), 607-610. 